
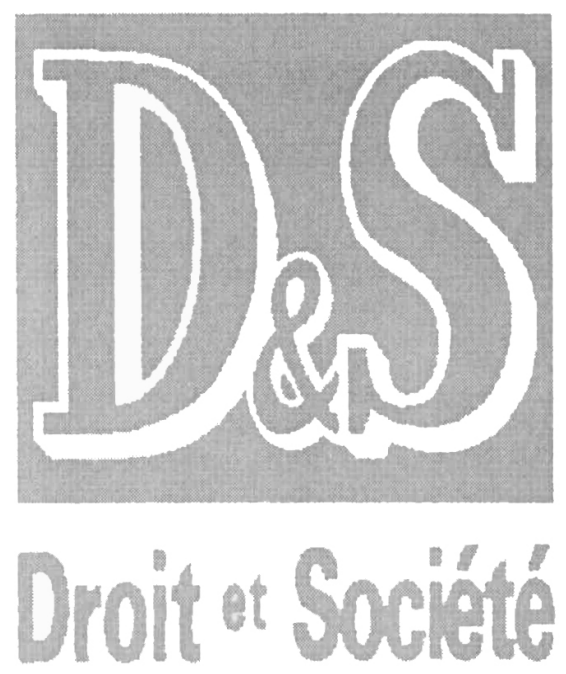

Revue publiée avec le concours du Centre National de la Recherche Scientifique (France)

ISSN 0769-3362

\section{Administration et abonnements}

Librairie Générale de Droit et de Jurispnudence, 31 , rue Falguière

F-75741 Paris Cedex 15

Tél.: 01.56.54.16.00 Fax:01.56.54.16.49

\section{Secrétariat de rédaction}

Ressource pourla Recherche Justice,

54, rue de Garches, F-92420 Vaucresson

e-mail:lesavre@ext.jussieu.fr

Tél::01.47.95.98.66 Fax:01.47.01.41.48

Au sommaire du numéro 40-1998

\title{
Dossier :
}

Produire la loi

Jacques Commaille:Présentation

Marta Gracia Blanco: Codification et droit de la postmodernité : la création du nouveau Code pénalespagnol de 1995

Martine Kaluszynski :Les artisans de la loi. Espaces juridico-politiques en France sous la II/ République

Stéphane Enguéléguélé: Lescommunautésépistémiques pénales etlaproductionlégislative en matière criminelle

\section{Études}

Pierre Noreau : La superposition des confits : limites de linstitution judiciaire comme espace de résolution

Flora Leroy-Forgeot:Culture britannique etculture européenne :éléments d'une évolution politico-juridique

Michel Coutu : Citoyenneté etlégitimité. Le patriotisme constitutionnei comme fondement de la référence identitaire

Et la rubrique Chronique bibliographique 


\section{CANADIAN JOURNAL OF LAW AND SOCIETY REVUE CANADIENNE DROIT ET SOCIETE}

The Journal has existed since 1985. Founded by Rainer Knopff, with the assistance of Ann Griffith, it was initially based in the Research Unit for Socio-Legal Studies of the University of Calgary. Since June 1990, it has been affiliated with the Canadian Association of Law and Society. Its editorship was then transferred to the Université du Québec a Montreal, so as to commence the rotation of this function among different Canadian universities. Thanks to the financial support of the Universite du Québec a Montréal, as of the transfer the Journal became a biannual review beginning with Volume 7 (1992), and certain issues are devoted to specific themes. The Canadian Journal of Law and Society seeks the promotion and publication of research on law and legal systems understood as social phenomena. The Journal is interdisciplinary, calling for diverse methods of analysis and perspectives on law.

The Journal was published by the University of Calgary Press up to Volume 9, 11 and is now published at the Universite du Quebec à Montreal. It is funded by the Social Sciences and Humanities Research Council of Canada and the Université du Québec à Montréal.

The Joumal is indexed in the Corpus Almanac \& Canadian Sourcebook; the Standard Periodical Directory; the Oxbridge Data Center; the Canadian Periodical Index; Ulrich's International Periodicals Directory; Dustbooks/The International Directory of Little Magazines and Small Presses; the Index to Canadian Legal Periodical Literature; WESTLAW; the Index to Legal Periodicals; Sociological Abstract; Current Legal Sociology; Criminal Justice Abstract; Felix Dietrich Verlag GmbH \& Co KG, IBZ-International Bibliography for Periodical Literature; Novaya Literatura po Sotsialistnym i gumanitarnym naukam, Gosudarstvo i Pravo (New Literature in the Social and Humanitarian Sciences, Government and Truth).

The index of all articles, comments, and review essays is published in Volume 12 \#2 (1997).

Instructions to authors are detailed on page 239.

La Revue existe depuis 1985. D'abord installe a The University of Calgary, auprès du Research Unit for Socio-Legal Studies, Faculty of Social Sciences, elle a té crete par Rainer Knopff assiste de Ann Griffith. Depuis juin 1990, la Revue est rattaché a l'Association canadienne Droit et SociGté et la rédaction a eté transferé à l'Université du Québec à Montréal, de façon à en permeture la rutation dans les differentes universites canadiennes. Grice à l'appui financier de l'Universite du Qucbec a Montréal, elle devient, avec ce transfert, une revue bi-semestrielle à partir du Volume 7 (1992) et certains numéros sont thématiques. La Revue canadienne Droit et Société vise à promouvoir la publication des recherches portant sur le droit et les systèmes juridiques, entendus comme phenomines sociaux. La Revue est interdisciplinaire, faisant appel aux diverses perspectives et methodes d'analyse du droit.

La Revue a été publiće par University of Calgary Press jusqu'au Volume 9 \#1. Elle est maintenant publice a l'Université du Quebec à Montréal. Elle est subventionné par le Conseil des recherches en Science humaines du Canada et par l'Université du Québec a Montréal.

La Revue est repertorice dans Corpus Almanac \& Canadian Sourcebook; Standard Periodical Directory; Oxbridge Data Center; Canadian Periodical Index; Ulrich's International Periodicals Directory; Dustbooks/The International Directory of Little Magazines and Small Presses; Index to Canadian Legal Periodical Literature; WESTLAW; Index to Legal Periodicals; Sociological Abstract; Current Legal Sociology; Criminal Justice Abstract; Felix Dietrich Verlag GmbH \& Co KG, IBZ-International Bibliography for Periodical Literature; Novaya Literatura po Sotsialistnym i gumanitarnym naukam, Gosudarstvo i Pravo (New Literature in the Social and Humanitarian Sciences, Government and Truth).

L'index de tous les articles, commentaires et notes critiques est publié dans le Volume $12 * 2$ (1997).

Les recommandations aux auteurs pour la soumission des manuserits se trouvent à la page 240. 
Andrée Lajoie, Jugements de valeur: Le Discours judiciaire et le droit Charles-Albert Morand

Alain Gallusser, L'Indice matériel comme moyen de preuve.

Sa valeur et son utilisation par les magistrats

François-Xavier Ribordy

Ngaire Naffine, Feminism and Criminology

Mariana Valverde

Clayton James Mosher, Discrimination and Denial:

Systemic Racism in Ontario's Legal and Criminal Justice Systems, 1892-1961

Barrington Walker

All manuscripts should be sent to the

Editor at the following address:

Les manuscrits doivent être envoyés à l'attention du directeur de la Revue à l'adresse suivante:

Departement des Sciences juridiques

Université du Québec à Montréal

C.P. 8888, succursale Centre-ville

Montréal, Québec, Canada, H3C 3P8

Tél.: (514) 987-3000, poste 4712\#

FAX: (514) 987-6548
Please address all subscription orders and change of address to:

Pour les abonnements et les changements d'adresse, veuillez écrire à l'adresse ci-dessous:

Service des publications Université du Québec à Montréal C.P.8888, succursale Centre-Ville Montréal, Québec, Canada, H3C 3P8 Tél.: (514) 987-3000, poste 4229; FAX: (514) 987-0307

Internet: http://www.juris.uqam.ca/reds/index.htm 